\title{
Teaching Material Development Based on German Literature for Lesen Course in German Literature Study Program
}

\author{
Lutfi Saksono \\ Universitas Negeri Surabaya \\ Surabaya, Indonesia \\ lutfisaksono@unesa.ac.id
}

\author{
Fahmi Wahyuningsih \\ Universitas Negeri Surabaya \\ Surabaya, Indonesia \\ fahmiwahyuningsih@unesa.ac.id
}

\author{
Rr Dyah Woroharsi Parnaningroem \\ Universitas Negeri Surabaya \\ Surabaya, Indonesia \\ dyahworoharsi@unesa.ac.id
}

\begin{abstract}
The purpose of teaching a foreign language is to help students in improving their skill in oral and written communication. One of language skills that needs to be improved is reading skill. In German Literature study program, reading skill is gained in Lesen course. Lesen 1 course is a basic skill course for German Literature students in Universitas Negeri Surabaya, and it is compulsory to be taken by the students in their first semester of their study. This study is qualitative, which involved college students in German literature study program. For collecting the data, German literature texts are used. In results, the material development which used literature-based guides and helps the students to be better according to the German literature competency. Those texts help the students to improve their reading skill, grammatical skill, cultural understanding, and even their imagination. A good and appropriate literary text for Lesen 1 course is the one with a simple and basic structure such as Praesens, Perfekt, and Praeterium. If there is a text that is too complicated, then it needs to be simplified first to adjust the students' ability.
\end{abstract}

Keywords- teaching material development, literary text, reading skill

\section{INTRODUCTION}

Learning German as a foreign language (Deutsch als Fremdsprache/DaF) becomes a challege for learners. It is because they should acquire the skill of German language. There are four language skills that hold a very important role. Those four language skills are divided into two aspects, the aspect of active receptive and active productive. The language skills that are included in the aspect of active receptive are listening and reading. These aspects deal with information management which are received by one which later on might be useful for the two skills in active productive, which are speaking and writing.

In German Department in Universitas Negeri Surabaya, those four skills are given separately, especially in the first and second semester. The total of credit hours of each language skill is 4 credit hours, which means in the first and second semester each student will have 16 credit hours of language skills.

Even though the courses have different names and schedules, the book that is used is still the same, which is Studio D. For four language skills in the first semester, the book that is used is Studio D A1. One Studio D book has already included every language skill. While in the second semester, the book that is used is Studio D A2.

That particular book, Studio D, has been used for learning those four language skills in various universities in Indonesia, especially the ones that have German major. But for German Literature program in Universitas Negeri Surabaya, Studio D A1 and other teaching media have their own flaws, they don't have any literary texts. For German Literature program, the introduction of German literature should play a very important role since the start of the beginners, because literary work can spark the students' curiosity about German and its culture.

According to Rösler dan Würffel [1], teaching materials are made for a particular learning group, for instance a group of children of a group of adults. But it does not necessarily mean that the materials are appropriate for those group. Sometimes there are some materials that are printed by particular companies which has a target customer, so the printed books will be bought by them. Therefore, an educator has to be thorough in choosing the appropriate material for their students.

There are several criteria that is used by Rösler dan Würffel [1] to determine the appropriateness of a teaching material for the learners. These criteria are the level of knowledge of a particular language, interest and motivation, learning habit, learning purpose, a direct contact with a native speaker, and language learning experience.

According to what Rösler and Würffel [1] have said, then it can be concluded that choosing Studio D as a learning method ignores two factors, the purpose of learning and the students' interest in learning the language. Here, the aim of learning the language is the goal of learning German Literature supports its 
profile. The profile of German Literature graduates are people who are fluent in German. Therefore, in order to support German Literature's profile, the students need to be acquainted with German literary texts.

The usage of literary text in learning German is not something new. According to Rösler and Würffel [1] in 1990s, German Goethe Institute had asked some authors to write literary texts that can be used in the learning process of German. The learning materials (Lernmaterialien) which were made by the authors, like Mirjam Pressler and Christine Nöstlinger, are appropriate to be used for youngsters who are currently studying German.

The presence of German literary text in language learning can be taken advantage of for enhancing language skills, reading, listening, speaking, and writing [2]. Borrowed the term positivism, "positive correlation," to depict the relationship between literature and language learning as well as other learning subjects[1].

\section{A. Learning Materials}

The learners' age is important every learning material in foreign language learning. Commonly, the learners' age is divided into children, teenagers, and adults. Even though the learners are on the same age, sometimes they are still different in term of the knowledge due to their location, for instance, a teenager in Bogota and Surabaya. Besides, the theme and the learning activity between children, teenagers, and adults is also different. These differences are caused by the different cultural context [1].

Unlike children and teenager, adult learners have a clear interest and goal in learning a language [1]. If they are used to learning a foreign language, then they could follow the materials easily. Some adult learners can learn grammar well and they could use it because they already have many experiences in learning. In contrast, there are some learners who never learn a foreign language and some fear to learn a foreign language. These differences in language and life experiences will determine the knowledge and the learning experience just like what will be given to a particular study group.

To complete the learning materials, then additional materials are needed. In a broader perspective, additional materials include everything that is used by the educators which function as an additional information of the learning materials[1]. Additional materials in foreign language learning can be taken from actual phenomena which originated from the Internet or books.

According to Rösler and Würffel [1], additional information can be divided into (1) a developed material that is based on a learning principle, such as practices from a grammar book, or practices outside the learning principle, such as television (2) whether the materials that have a connection with some particular teaching materials or not.

Rösler and Würffel [1] have said that additional materials can be beneficial in some ways, such as (1) giving language phenomena; (2) they contain a variety of learning activities; (3) they give a chance to the learners to learn independently;
(4) can be understood by the learners according to their knowledge; (5) exam materials.

In choosing additional materials, there are some requirements that have to be fulfilled. Those requirements are good understanding of the learners, the difficulty that the learners encounter, and the appropriateness of the materials to the learning process [1].

According to what has been written above, it can be concluded that there are some things that align with the development of teaching materials, which are the purpose of study, study group (Lerngruppe), the learners' interest, the difficulty that the learners ' encounter, and the appropriateness with the learning process.

\section{B. Reading Comprehension}

Reading means activating a knowledge that has a connection with text, context, and the world. People who read also use reading strategies. Readers construct text in an interactive process between their possessed knowledge and the text's information [3].

To understand a text that is read then a correct reading strategy is needed. This strategy is supposed to be known since the beginning or since they are beginners. At least there are two reading strategies that are important, which are cognitive strategy and metacognitive strategy. Through these strategies, the readers can coordinate and control their understanding process.

To improve their reading skill, then practices need to be done. These practices can also help the readers to use their reading strategy. According to Rösler and Würffel [1], commonly practice in reading skill is divided into practice before reading, during reading, and after reading. Practices in educational books that can support readers“ understanding usually contain these strategies (1) finding unfamiliar words according to the context; (2) understanding key words; (3) using additional titles as understanding orientation to the text; (4) understanding important information in the text and limit irrelevant information; (5) guessing the text; (6) testing the guesses; (7) visualizing and picturing the text's structure; (8) asking relevant questions about the text; (9) connecting the dots between their knowledge and the new information that they gain; and (10) using reading strategies.

The development of teaching materials for reading skill can refer to what Rösler and Würffel's [1] opinion. Their opinion opens a possibility in learning skill to understand a text. In learning reading skill, the understanding of a text or the most important aspect.

\section{ADDIE-Model}

There are many model that can be used for the development of teaching materials, such as Dick and Carey, Kemp and Dick, PPSI, IDI, ASSURE, ADDIE, and many more. For instance, ADDIE model said that making a program or teaching material which will be used for a learning program is the third step after analysis and design. This development step contains creating, buying, and modifying teaching materials to reach the goal. Thus, several thoughts that are produced by this model are (a) what kind of teaching material 
that has to be prepared to fulfil the students' unique and specific needs, and (b) how to combine the needed media in order to hold a learning program.

In ADDIE model, evaluation has to be done in every stage. In analysis stage, there has to be an evaluation that can be used to continue to the following step, which is design. It is also like that in developing and implementation stage. After the implementation is finished, the development keeps going. It will keep being done based on the result of the evaluation [4].

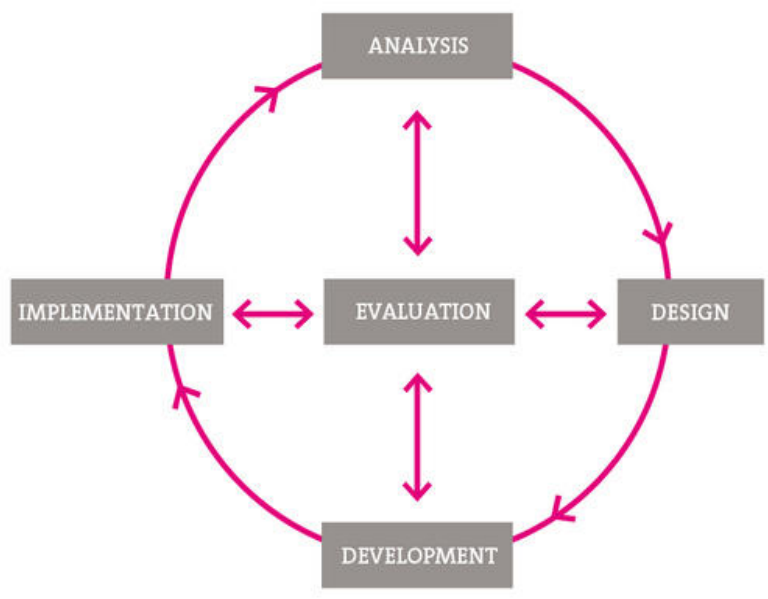

ADDIE Cycle Model

The implementation of a learning system design in a school shows the readiness of the educators to create an effective, efficient, and interesting learning activities. To create such thing, the teachers need to truly understand the materials that they are delivering. Besides that, their creativity is also needed to accomplish the goal.

\section{METHOD}

This study is qualitative. In which involved students of German Literature program, in Lesen course. Lesen 1 course is a basic skill course for German Literature students in State University Surabaya, and it is compulsory to be taken by the students in their first semester of their study. In order to learn in that class, German literature texts are used. In data collection and data analysis, the researchers used ADDIEModel for developing teaching materials, the researchers applied analysis, design, development, implementation, and evaluation.

\section{RESULT AND DISCUSSION}

\section{A. Needs Analysis}

Studio D was written by Hermann Funk, Christina Kuhn, and Silke Demme. Hermann Funk is a professor of German language in Jena University, while Christina Kuhn and Silke
Demme are from Institute of Goethe, an institution of German language.

Studio D A1 is represented with Start auf Deutsch. A chapter that describes German language and how life is in countries that use German as their first language, such as Germany, Austria, and Swiss. Studio D A1 is divided into 12 chapters, they are based on the theme and they also contain the development of mastering grammar (thematische und grammatische Progression). Those 12 chapters are titled Cafe $d$, im Sprachkurs, Staedte-Laender-Sprache, Menschen und Haeuser, Termine, Orientierung, Berufe, Berlin sehen, Ferien und Urlaub, Essen und trinken, Kleidung und Wetter, and Koerper und Gesundheit.

Every chapter of Studio D A1 offers many practices for four language skills, which are listening (Hören), speaking (Sprechen), writing (Schreiben) and reading (Lesen). Those practices are given through interesting themes and texts about human and the cultures of German speaking countries. In every chapter, the learners can compare their own life experience and the themes that are in the book.

Through Studio D A1, the readers are encouraged to learn level A1 German, in which the written texts or the spoken ones are already adapted to German daily conversation. The structures or the grammar are also for daily conversation or communicative. To ease the process of mastering German, there are also learning tips that focus on the development of independent learning. Which means the learners are able to learn German independently wherever they are. Besides, the authors of Studio D also use the term Station if the learner has reached chapter 5 .

In this Station, the learners can repeat, deepen, and broaden their previous material understanding. To make the learners understand particular words, they can see the attachment which is filled with the overview of grammar (Grammatikübersicht) and a list of words (Glossar). Also, in order to improve their listening and fix their pronunciation (Aussprache), the learners can play the audio through the CD and read while listening to the audio (Hörtexte).

Studio D is meant for adult learners. Therefore, this book also gives the importance of adulthood, such as office world, in order to give them an insight. The description above shows that Studio D is a book that has everything in it. No wonder why this book is used in many institutions that learn German all over the world, including Universitas Negeri Surabaya undergraduate program German Literature, even though that program needs to develop the book. The development of Studio D is based on the goal of the program that is made official in 2015. The goals are (1) able to act professionally by implementing the values that show moral, ethic, and good personality in completing their task, show compassion to the society and their surroundings and also has the will to be selfless for the country and the society; (2) able to demonstrate spoken and written German correctly according to the context like GER B2; (3) able to create a review and edit many kinds of spoken and written texts in German by implementing relevant literature that has been studied; (4) able to produce German text independently, creatively, and innovatively 
according to language and literary principles and even creative writing; (5) able to translate a German text to Bahasa Indonesia and vice versa by implementing literary and language principles; (6) able to appreciate and critic literary work by using literary theories; (7) able to plan, do, and report a research and develop German language and literature using many language and literary methods in written and spoken texts; (8) understand theoretical concept of language and literature and able to solve language and literary problems in procedural ways using scientific approach.

The learning goals above show that one of the competencies of German Literature students is mastering literary research concepts and also German culture. The knowledge about German literature is only obtained by the students when they reach the 3rd semester. While during their first year, they just revolve around language skills such as listening (Hören), speaking (Sprechen), writing (Schreiben), reading (Lesen), and also grammar (Strukturen). Which means in the first 2 semesters, the students never get introduced to German literature and text.

In Studio D A1, there is no text that is based on German literature or text about literature or the authors. Even German dialogues or descriptive texts are absent. Any knowledge about German literature since the early semesters will spark their interest and knowledge about it. Literary text could also be used for language learning on any level. Therefore, literarybased additional materials need to be further improved, these additional materials will complete Studio D.

\section{B. Design}

Literary-based additional materials for Studio D is designed for students who just start learning German. On the other hand, the students could also obtain a new knowledge about German literature. It is very important for them because it help them understand German culture and its surroundings which will help them in their future researches.

As that before, Studio D A1 has 12 chapters in it. To complete the German literary aspects of every chapter, the additional materials will be given in the form of German literary text or texts about the literary lives in German speaking countries. This text will be completed with practices to enhance the students' understanding about the text.

The text that will be used as an additional material is the text that is appropriate and is on the same level as A1. If it is not appropriate for A1 level, then that text is not the same as Studio D A1. The function of the additional materials is to help the usage of Studio D A1, because in that book there is no German literature related things in there that could give the students an insight of the literary lives and culture in Germany.

Literary text that is used is poem, prose, and drama. Commonly, to understand a literary text, it is needed a time for analysing the text, especially for people who are just beginners in German. But in literary text that will be given is children literature (Kinderliteratur) or texts that have been simplified. Besides, literary text will also be beneficial for the students, such as (1) gaining an aesthetic experience and understand language that is used in literature; (2) leading them into literary aspects in literature; (3) improving reading skill, articulation, speaking, and listening; (4) deepening the understanding process of literary work and improving their imagination; (5) improving their productivity and creativity; and (6) building a social awareness and starting the process of self-identification and social

Literary works can be used for improving one's language skill. One of the language skills that can be improved by literary text is reading skill. The enhancement of reading skill can be probed by reading the answers of the questions that are given to the students. Therefore, after the students are given a literary text, they should be given some practices to know their understanding of the given text.

According to the description above, it can be concluded that literary text or text that are connected to literature can be used for practice in Lesen class. Those texts can result in better reading skill, better understanding of grammar, culture, and developed imagination. A well-written literary text and appropriate for Lesen 1 is texts which grammar is still basic like praesens, perfekt, and praeteritum. If there is a complicated text then it could be simplified beforehand or adapted with the students' language skill.

\section{Implementation}

Literary-based additional material is to be applied in Lesen 1 class. Lesen 1 is a class that enhances the students' reading skill as it could help them to develop other skills such as writing, speaking, and listening skills.

In the implementation step, the students who take Lesen 1 will still use the book Studio D as their main source of learning as it is compulsory. While literary-based additional materials are used when the educators need them to be a part of their effort to help improving their reading skill and their understanding of grammar, which are the things that are absent in Studio D. They could also help broaden their culture knowledge, especially literary knowledge.

In the implementation process, the usage of the additional materials needs a lot of time especially if it encounters a long text. Even though there are long texts in Studio D, but they are supported by good explanations. To solve that problem, then the students can be asked to read the additional materials at their own home. Then, it will be the theme of the discussion the very next day.

\section{Evaluation}

Evaluation step is the scoring stage of the appropriateness of the teaching materials. In this stage, a validator scores the teaching materials based on several aspects from the validation sheet. These aspects are the appropriateness of the context, teaching delivery, the language, and graphic aspect.

The appropriateness of the context is about whether it is appropriate for level A1 or not, the content of the teaching is literature, the text is not too complicated, and it contains practices that complete Studio D A1. The aspect of teaching delivery contains a list of materials according to Bloom taxonomy order and the material order is according to the 
themes in Studio D. For the language aspect that is being observed is whether the grammar is appropriate for A1 level, the grammar that is given is the same as Studio D A1. For the aspect of graphic is the appropriateness of the book layout, the kind of alphabet that is being used, and intriguing cover.

According to the score from the validator, there are several things that need to be fixed, especially the length of the text. Long and complicated texts will confuse the students in Lesen 1 , because their vocabularies are still limited. Therefore, text such as Die Leiden des jungen Werther was not given completely, but only as parts that are important that are related to Werther's behaviour.

According to the description above, then the literary-based additional materials can be used to accompany the main book Studio D.

\section{CONCLUSION}

Literary text or texts that are related to literary lives can be used for the process of Lesen 1 class. Those texts produce practices that can improve reading, grammar, culture knowledge, and help improving the students' imagination. A good literary text for Lesen 1 is texts that use basic grammar such as Praesens, Perfekt, and Praeteritum. If there is a complicated text, then it needs to be simplified beforehand to adjust with the students' capability.

\section{REFERENCES}

[1] D. Rösler, and N. Würffel. Lernmaterialien und Medien. München: Klett-Langenscheidt. 2014

[2] Jürgen Quetz. Lernziele und Inhalte. In „Neue Sprachen lehren und lernen. Fremdsprachenunterricht in der Weiterbildung. Jürgen Quetz and Gerhard von der Handt (ed.). Bartelsmann Verlag Gmbh. 2002

[3] Eva Burwitz-Melzer and Jürgen Quetz. Methoden für den Fremdsprachenunterricht mit Erwachsene. In „Neue Sprachen lehren und lernen. Fremdsprachenunterricht in der Weiterbildung. Jürgen Quetz and Gerhard von der Handt (ed.). Bartelsmann Verlag Gmbh. 2002

[4] I. M. Tegeh, I. N. Jampel and Ketut Pudjawan. Model penelitian Pengembangan. Graha Ilmu 2014 